\title{
Carbofuran Modulating Functions of Acetylcholinesterase from Rat Brain In Vitro
}

\author{
Vivek Kumar Gupta, ${ }^{1}$ Ashutosh Pathak, ${ }^{1}$ Nikhat Jamal Siddiqii, ${ }^{2}$ and Bechan Sharma ${ }^{1}$ \\ ${ }^{1}$ Department of Biochemistry, Faculty of Science, University of Allahabad, Allahabad 211002, India \\ ${ }^{2}$ Department of Biochemistry, College of Science, King Saud University, P.O. Box 22452, Riyadh 11495, Saudi Arabia
}

Correspondence should be addressed to Bechan Sharma; sharmabi@yahoo.com

Received 16 August 2015; Revised 20 December 2015; Accepted 16 February 2016

Academic Editor: Vianney Pichereau

Copyright (C) 2016 Vivek Kumar Gupta et al. This is an open access article distributed under the Creative Commons Attribution License, which permits unrestricted use, distribution, and reproduction in any medium, provided the original work is properly cited.

\begin{abstract}
Carbofuran, a potential environmental xenobiotic, has the ability to cross blood brain barrier and to adversely influence brain functions. In the present study, the impact of carbofuran on the biophysical and biochemical properties of rat brain AChE has been evaluated in vitro. This enzyme was membrane-bound which could be solubilised using Triton-X100 ( $0.2 \%$, v/v), a nonionic detergent, in the extraction buffer $\left(50 \mathrm{mM}\right.$ phosphate, $\mathrm{pH}$ 7.4). The enzyme was highly stable up to one month when stored at $-20^{\circ} \mathrm{C}$ and exhibited optimum activity at $\mathrm{pH} 7.4$ and $37^{\circ} \mathrm{C}$. AChE displayed a direct relationship between activity and varying substrate concentrations (acetylthiocholine iodide (ATI)) by following Michaelis-Menten curve. The $K_{m}$ and $V_{\max }$ values as computed from the Lineweaver-Burk double reciprocal plot of the data were found to be $0.07 \mathrm{mM}$ and $0.066 \mu \mathrm{mole} / \mathrm{mL} / \mathrm{min}$, respectively. The enzyme exhibited $\mathrm{IC}_{50}$ value for carbofuran equal to $6.0 \mathrm{nM}$. The steady-state kinetic studies to determine mode of action of carbofuran on rat brain AChE displayed it to be noncompetitive in nature with $K_{i}$ value equal to $5 \mathrm{~nm}$. These experiments suggested that rat brain $\mathrm{AChE}$ was very sensitive to carbofuran and this enzyme might serve as a significant biomarker of carbofuran induced neurotoxicity.
\end{abstract}

\section{Introduction}

Carbofuran $\left(\mathrm{C}_{12} \mathrm{H}_{15} \mathrm{NO}_{3}\right.$; 2,3-dihydro-2,2-dimethyl-7-benzofuranol methylcarbamate, molecular weight, 221.25), commonly known as Furadan, is a broad spectrum carbamate pesticide which is used in various farm practices in order to increase crop productivity. Due to its broad spectrum action and short half-life in the environment, it is also used as an insecticide, nematicide, and acaricide $[1,2]$. The presence of carbofuran is also reported in the nontarget mammalian systems such as maternal plasma, umbilical cord, and blood of African-American women and new born babies, respectively [3]. It has been shown to be generally accumulated in the fat depots and exerts adverse effects on different vital organs such as brain, liver, skeletal muscles, and heart $[1,4,5]$. The neuronal injury of mammalian system due to carbofuran is due to the establishment of oxidative stress [6].

The underlying mechanism of pesticide toxicity relies on generation of oxidative stress [7]. The administration of carbofuran has been found to induce reactive oxygen and nitrogen species in skeletal muscles [8], which are responsible for the peroxidation of membrane phospholipids which disrupt the normal function of lipid bilayer and help develop several pathological conditions.

The in vivo studies carried out by administering a single sublethal dose of seven $\mathrm{N}$-methylcarbamate pesticides (carbaryl, carbofuran, formetanate, methiocarb, methomyl, oxamyl, or propoxur) indicated pesticide mediated AChE inhibition in the brain and red blood cells which recovered within $24 \mathrm{~h}$ after the withdrawal of the pesticide [9]. The earlier experimental results from our and other laboratories have established that treatment of rats with carbofuran in vivo was able to inhibit AChE activity and also to produce oxidative stress in liver [4], brain [6,10], kidney [11], and erythrocytes $[5,12]$.

Acetyl cholinesterase (AChE, EC 3.1.1.7) or acetyl hydrolase is a serine protease that hydrolyzes the neurotransmitter acetylcholine to be acetyl-S-CoA and choline. The AChE molecule composed of two different protein domains, 
a large catalytic domain of about 500 residues and a small C-terminal peptide of less than 50 resides [13], is a key enzyme of nerve impulse transmission and is reported to be negatively modulated by carbofuran. The AChE occurs with high specific activity in the brain and nervous tissues, as well as in the membranes of muscles and erythrocytes [14]. AChE has been the focus of much attention since it was first suggested that it plays an important role in the rapid destruction of the neurotransmitter acetylcholine (ACh), in a living system [15]. The catalytic properties, occurrence of $\mathrm{AChE}$, its histochemical localization, catalytic functions, and molecular heterogeneity in different tissues of various animal species have been extensively studied [16-20].

However, the systematic and detailed studies concerning the localization as well as biochemical properties of $\mathrm{AChE}$ with special reference to its interaction in vitro have not been properly carried out. In the present paper, the aforesaid properties of rat brain AChE have been determined in vitro with special attention to its steady-state kinetics explaining sensitivity of enzyme to carbofuran and its mode of action influencing the enzyme behavior which have been illustrated. The results indicated that rat brain AChE could be exploited as a suitable biomarker of pesticide induced neurotoxicity.

\section{Materials and Methods}

2.1. Chemicals. S-Acetylthiocholine iodide (ATI) was obtained from Tokyo Chemical Industry Co. Ltd., Japan, and 5, $5^{\prime}$-dithiobis (2-nitro benzoic acid) (DTNB) was purchased from SRL Pvt. Ltd., India. Triton X-100 was purchased from Merck, India. The bovine serum albumin (BSA), sodium dihydrogen orthophosphate, and disodium hydrogen phosphate were procured from Fisher Scientific. Folin and Ciocalteu's phenol reagent was from Spectrochem Pvt. Ltd., India. All other chemicals used were of analytical grade.

2.2. Animals. Three male albino rats of same age group, weighing $180-210 \mathrm{~g}$, were selected for all these experiments. Animals obtained from CDRI, Lucknow, India, were housed in propylene cages at $30 \pm 5^{\circ} \mathrm{C}$ and $45 \pm 5 \%$ relative humidity with $12 \mathrm{~h}$ of light and dark cycle. Animals were fed with standard rat feed available commercially with free access to water. Protocols for care and maintenance of the rats were strictly followed as per the guidelines approved by the institutional ethical committee.

\subsection{Collection of Brain Tissues and Preparation of Homo-} genates. The healthy rats were sacrificed using mild chloroform anesthesia and cervical dislocation causing minimal pain. The whole brain was quickly excised, washed with isotonic ice cold $\mathrm{NaCl}(0.9 \%, \mathrm{w} / \mathrm{v})$ solution, blotted to dryness, and weighed. The brain tissue homogenate $(10 \%$, $\mathrm{w} / \mathrm{v}$ ) was made in $50 \mathrm{mM}$ sodium phosphate buffer $(\mathrm{pH}$ 7.4) with and without Triton X-100 (0.2\%, v/v) using PotterElvehjem homogenizer fitted with a Teflon coated pestle under ice cold condition $\left(4-6^{\circ} \mathrm{C}\right)$. The homogenates were centrifuged at $9000 \times \mathrm{g}$ for $30 \mathrm{~min}$ using REMI refrigerated centrifuge. The supernatants were removed and the pellets were reconstituted in equal volume of homogenizing buffer. Both the supernatants and the pellets suspensions were used for protein estimation and determination of AChE activity. The soluble fraction was assayed for detailed characterization of enzyme including its interaction with carbofuran in vitro.

2.4. Determination of Protein. The protein was estimated in different fractions of rat brain using Folin and Ciocalteu's phenol reagent [21]. The bovine serum albumin was used as an standard. The absorbance of blue color complex was monitored at $620 \mathrm{~nm}$.

2.5. Assay of Rat Brain Acetylcholinesterase Activity. The activity of rat brain AChE was determined by the method of Ellman [22]. The $3 \mathrm{~mL}$ reaction mixture contained $0.5 \mathrm{mM}$ ATI, $0.5 \mathrm{mM} \mathrm{DTNB}$, and $50 \mathrm{mM}$ phosphate buffer (pH 7.4). The change in absorbance of light was measured at $412 \mathrm{~nm}$ for $3 \mathrm{~min}$ at regular intervals of $30 \mathrm{sec}$ using UV-Visible double beam spectrophotometer (Thermo Scientific Spectroscan UV 2700). The extinction coefficient $\left(13.6 \times 10^{3} \mathrm{M}^{-1} \mathrm{~cm}^{-1}\right)$ was used for calculation of the enzyme activity. It was expressed as units $(\mathrm{U})$, that is, $\mu$ moles of acetylthiocholine (ATI) hydrolyzed $\mathrm{mL}^{-1} \mathrm{~min}^{-1}$. The substrate or enzyme blanks, respectively, were without substrate or enzyme. The experimental observations were corrected by subtracting the absorbance $\mathrm{min}^{-1}$ recorded in controls.

2.6. Effect of Substrate on Enzyme Activity. To determine the effect of substrate concentration on the activity of enzyme, the enzyme $(100 \mu \mathrm{g})$ was assayed at varying substrate (ATI) concentrations at the room temperature $\left(26 \pm 2^{\circ} \mathrm{C}\right)$ and the Michaelis-Menten constant $\left(K_{m}\right)$ and maximum velocity $\left(V_{\max }\right)$ were computed.

2.7. Determination of Effect of Incubation Time on Carbofuran Induced Inhibition of Enzyme. The $100 \mu \mathrm{g}$ enzyme was added with $2 \mathrm{nM}$ carbofuran and assayed for its residual activity at different time intervals ( $0 \mathrm{~min}$ to $120 \mathrm{~min}$ ) at room temperature $\left(26 \pm 2^{\circ} \mathrm{C}\right)$. The enzyme activity recorded at these time points in absence of carbofuran served as controls. The zero time reaction refers to the reaction rate measured immediately after mixing the enzyme with other reagents.

\subsection{Determination of $I C_{50}$ Value for Enzyme Inhibition by} Carbofuran. The $100 \mu \mathrm{g}$ enzyme was used to monitor the residual activity by assaying it in the presence of varying concentrations of carbofuran. The control set of reaction did not contain carbofuran and the activity recorded was considered as $100 \%$. The $\mathrm{IC}_{50}$ value was calculated by extrapolating the data.

2.9. Determination of Mechanism of Inhibition of AChE by Carbofuran. The $K_{i}$ and $V_{\max }$ values were determined by assaying the enzyme $(100 \mu \mathrm{g})$ at varying concentrations of ATI in the absence and presence of carbofuran $(2.0 \mathrm{nM})$ and plotting the graph using inverse of rate of reaction and substrate concentrations on $Y$ - and $X$-axes, respectively. The 
TABLE 1: Extraction of rat brain acetylcholinesterase.

\begin{tabular}{lccc}
\hline Extraction buffer & Fractions & Total activity $(\mu \mathrm{mole} / \mathrm{mL} / \mathrm{min})$ & Total protein $(\mathrm{mg})$ \\
\hline \multirow{2}{*}{ Phosphate buffer (50 mM, pH 7.4) } & Supernatant & 0.165 & 7.75 \\
& Pellet & 0.562 & 3.05 \\
\hline Phosphate buffer with Triton X-100 (0.2\% v/v) $(50 \mathrm{mM}, \mathrm{pH} 7.4)$ & Supernatant & 0.990 & 15.75 \\
& Pellet & 0.275 & 1.20 \\
\hline
\end{tabular}

One unit of the activity of AChE has been defined as the micromoles of substrate hydrolyzed per min per mL.

intersections by the straight line at the $Y$ - and at the $X$-axes, respectively, of the Lineweaver-Burk's double reciprocal plot were used for calculations of the above parameters.

2.10. Determination of $K_{i}$ of Carbofuran. The mechanism of inhibition of enzyme by carbofuran was determined by assaying the enzyme as described in Section 2.9. The following formulae were used: $V_{\max }+I=V_{\max }-I / 1+[I] / K_{i}$ or $K_{m}+I=K_{m} / 1+[I] / K_{i}$, where $V_{\max }+I$ and $V_{\max }-I$ are the maximal velocities of reactions in the presence and absence of carbofuran. Similarly, $K_{m}+I$ and $K_{m}$ denote the $K_{m}$ values in the presence and absence of carbofuran. $[I]$ represents the concentration of inhibitor used, that is, $2.0 \mathrm{nM}$. The $K_{i}$ value may also be calculated using $K_{i}=\mathrm{IC}_{50} / 1+[S] / K_{m}$.

2.11. Statistical Analysis of Data. Statistical analysis of data was performed using Graph Pad Prism version 6 for windows. All values were expressed as mean standard deviation of 3 observations.

\section{Results}

3.1. Localization of AChE from Rat Brain. In order to localize the enzyme protein from the rat brain, one part of the tissue was treated with Triton X-100 $(0.2 \%, \mathrm{v} / \mathrm{v})$, a nonionic detergent, in phosphate buffer $(50 \mathrm{mM}, \mathrm{pH} 7.4)$ to solubilise the membrane-bound protein. It was observed that the detergent solubilised fraction contained more enzyme activity than that of without detergent. The results of this experiment indicated that $\mathrm{AChE}$ in rat brain was membrane-bound. The quantity of protein was also found to be higher in the soluble fractions, the values being $3.15 \mathrm{mg} / \mathrm{mL}$ protein as against $1.55 \mathrm{mg} / \mathrm{mL}$ in the fraction not treated with the detergent. The pellet with Triton X-100 contained $1.20 \mathrm{mg} / \mathrm{mL}$ against $3.05 \mathrm{mg} / \mathrm{mL}$ in the fraction obtained without treatment with the detergent (Table 1).

3.2. Effect of Low Temperature $\left(-20^{\circ} \mathrm{C}\right)$ on the Stability of Enzyme Activity. The effect of low temperature $\left(-20^{\circ} \mathrm{C}\right)$ was studied on the activity of rat brain AChE by storing the enzyme at this temperature and assaying for its activity using $100 \mu \mathrm{g}$ protein at the interval of 7 days. The data summarized in Table 2 demonstrated that the enzyme did not lose any activity up to 30 days.

3.3. Impact of Optimum $p H$ for the Rat Brain AChE. The enzyme was assayed at constant concentration of substrate $(0.5 \mathrm{mM})$ and enzyme $(100 \mu \mathrm{g})$ for the determination of $\mathrm{pH}$
TABLE 2: Stability of rat brain AChE activity.

\begin{tabular}{lcc}
\hline Days & \% AChE activity remaining & AChE activity \\
\hline 0 & 100 & 0.132000 \\
7 & 100 & 0.132000 \\
14 & 99.8 & 0.131736 \\
21 & 99.8 & 0.131736 \\
28 & 99.5 & 0.131340 \\
30 & 99.5 & 0.131340 \\
\hline
\end{tabular}

Effect of storage time at $-20^{\circ} \mathrm{C}$ on the activity of AChE from rat brain was observed by carrying out the enzyme assay employing $100 \mu \mathrm{g}$ protein on different days as described in Section 2. The enzyme was stored in phosphate buffer (50 mM, pH 7.4) containing $0.2 \%$ Triton X-100.

TABLE 3: Effect of $\mathrm{pH}$ on the rat brain AChE activity.

\begin{tabular}{lc}
\hline $\mathrm{pH}$ & Activity $(\mu \mathrm{mole} / \mathrm{mL} / \mathrm{min})$ \\
\hline 3.6 & 0.06 \\
5.0 & 0.07 \\
6.3 & 0.07 \\
7.4 & 0.13 \\
9.2 & 0.11 \\
10.0 & 0.08 \\
\hline
\end{tabular}

Effect of $\mathrm{pH}$ at room temperature $\left(26 \pm 2^{\circ} \mathrm{C}\right)$ on the activity of AChE from rat brain was observed by carrying out the enzyme assay employing $100 \mu \mathrm{g}$ protein at different $\mathrm{pH}$ of different buffers (sodium acetate buffer for $\mathrm{pH} 3.6$ and 5.0, sodium phosphate buffer for $\mathrm{pH} 6.37$ and 7.4, and carbonate buffer for $\mathrm{pH} 9.2$ and 10.0) as described in Section 2. The enzyme was stored in phosphate buffer $(50 \mathrm{mM}, \mathrm{pH} 7.4)$ containing $0.2 \%$ Triton X-100.

optima at room temperature $\left(26 \pm 2^{\circ} \mathrm{C}\right)$. The different buffers used were sodium acetate buffer for $\mathrm{pH} 3.6$ and 5.0; sodium phosphate buffer for $\mathrm{pH} 6.37$ and 7.4; carbonate buffer for $\mathrm{pH}$ 9.2 and 10.0 as described in Section 2. The results presented in Table 3 demonstrated that the enzyme exhibited maximum activity at $\mathrm{pH}$ 7.4. The enzyme assayed in buffers of higher $\mathrm{pH}$ values displayed inhibitory effect.

3.4. Effect of Optimum Temperature for the Rat Brain AChE. The enzyme was assayed at constant concentration of substrate $(0.5 \mathrm{mM})$ and enzyme $(100 \mu \mathrm{g})$ at $\mathrm{pH} 7.4$ by incubating the enzyme at different temperatures for $5 \mathrm{~min}$ for the determination of temperature optima as described in Section 2. AChE from rat brain was found to exhibit optimum activity at $37^{\circ} \mathrm{C}$. The increase in temperature, however, caused gradual loss in its activity of enzyme (Table 4 ). 
TABLE 4: Effect of temperature on the rat brain AChE activity.

\begin{tabular}{lc}
\hline Temperature $\left({ }^{\circ} \mathrm{C}\right)$ & AChE activity $(\mu \mathrm{mole} / \mathrm{mL} / \mathrm{min})$ \\
\hline 4 & 0.057 \\
10 & 0.072 \\
20 & 0.072 \\
37 & 0.096 \\
40 & 0.087 \\
50 & 0.061 \\
60 & 0.008 \\
75 & 0.005 \\
\hline
\end{tabular}

Effect of varying temperatures on the activity of AChE from rat brain was observed by carrying out the enzyme assay employing $100 \mu \mathrm{g}$ protein at $\mathrm{pH}$ 7.4 of phosphate buffer as described in Section 2. The enzyme was stored in phosphate buffer $(50 \mathrm{mM}, \mathrm{pH} 7.4)$ containing $0.2 \%$ Triton X-100.

3.5. Effect of Substrate Concentration on the Activity of Rat Brain AChE. In order to evaluate the effect of substrate (ATI) concentration on the activity of the enzyme, $100 \mu \mathrm{g}$ of protein was used with varying concentrations of the substrate (ATI) at room temperature $\left(26 \pm 2^{\circ} \mathrm{C}\right)$. The enzyme activity indicated a direct correlation with the substrate displaying a hyperbolic curve (Figure 2(a)). When the data was extrapolated using inverse of rate of reaction $(v)$ and the substrate concentration $[S]$, a straight line was obtained which intersected at $Y$ - and at the negative abscissa of $X$-axes. The calculated $V_{\max }$ and $K_{m}$ values were found to be $0.066 \mu$ moles $\mathrm{mL}^{-1} \mathrm{~min}^{-1}$ and $0.07 \mathrm{mM}$, respectively.

3.6. Effect of Carbofuran on the Rate of Reaction Catalyzed by Rat Brain AChE. The effect of carbofuran on the rate of reaction catalyzed by rat brain $\mathrm{AChE}$ was determined by assaying the activity in the presence of different concentrations of carbofuran $(0-200 \mathrm{nM})$. The results indicated consistent decrease in enzyme activity. After extrapolation of the data using percent residual activity and the carbofuran concentrations on $Y$ - and $X$-axes, respectively, the $\mathrm{IC}_{50}$ value of this pesticide for rat brain enzyme was found to be $6.0 \mathrm{nM}$ (Figure 3 and Table 5).

3.7. Time Dependent Impact of Carbofuran on the Rate of AChE Catalyzed Reaction. In order to evaluate the effect of incubation time on the carbofuran induced inhibition of the activity AChE from rat brain at room temperature $\left(26 \pm 2^{\circ} \mathrm{C}\right)$, the enzyme $(100 \mu \mathrm{g})$ was assayed at different durations in both the absence and the presence of the carbofuran $(2.0 \mathrm{nM})$. The enzyme activity in the absence of pesticide acted as a control. The results presented in Figure 1 demonstrated that the enzyme activity did not change with increasing duration of incubation in the presence of carbofuran when compared at zero time point. The results also demonstrated that carbofuran at this concentration $(2.0 \mathrm{nM})$ caused sharp inhibition of the enzyme. However, in the absence of the pesticide, the enzyme activity was fund to be highly stable at room temperature as it did not show any decrease in activity at increasing incubation time up to 60 min under similar assay conditions (Figure 1).

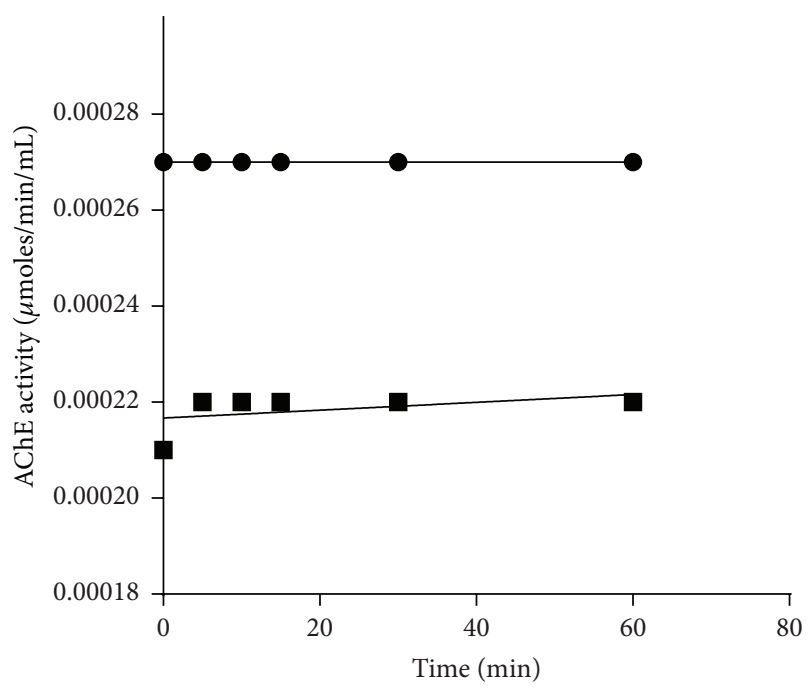

$$
\begin{aligned}
& -\bullet-I \\
& -\square+I
\end{aligned}
$$

FIGURE 1: Effect of carbofuran $(2 \mathrm{nM})$ on the activity of AChE from rat brain with respect to the varying incubation time at room temperature $\left(26 \pm 2^{\circ} \mathrm{C}\right)$. The enzyme assay was carried out employing $100 \mu \mathrm{g}$ protein using the procedure as described in Section 2. The results indicate the average values of three independent experiments. The enzyme in the absence of carbofuran served as a control and did not show any decrease in activity. $+I$ and $-I$ demonstrate the activity of AChE in the presence and absence of carbofuran.

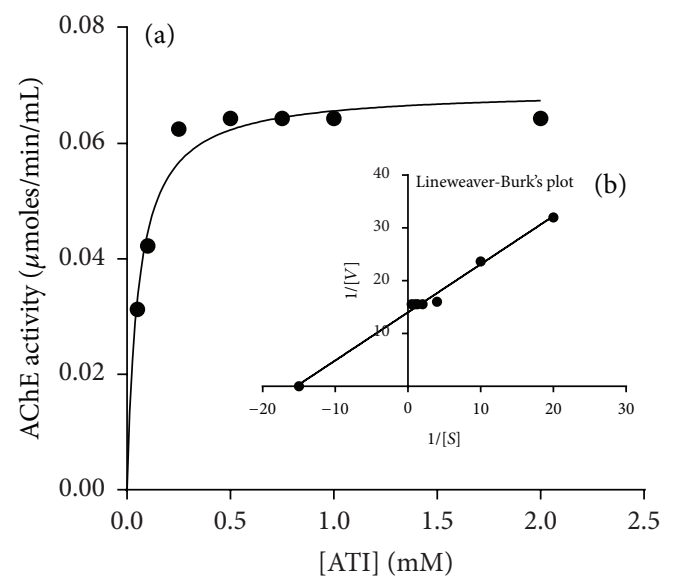

FIgURE 2: Effect of substrate (ATI) on the activity of AChE from rat brain was observed by assaying the enzyme at varying concentration ATI at room temperature $\left(26 \pm 2^{\circ} \mathrm{C}\right)$ as described in Section 2 employing $100 \mu$ g protein (a). The $K_{m}$ and $V_{\max }$ values were calculated using the intersection of the straight line at $Y$-axis and at the negative abscissa on $X$-axis, respectively (b). $[\mathrm{V}]$ is rate of reaction and $[S]$ is substrate concentration.

3.8. Determination of Mechanism of Inhibition of Enzyme by Carbofuran. The results from the previous experiments indicated that carbofuran was causing significant inhibition of rat brain AChE. It was therefore envisaged to determine the mechanism of enzyme inhibition by carbofuran by assaying the enzyme $(100 \mu \mathrm{g})$ using varying substrate concentrations 
TABLE 5: Determination of $\mathrm{IC}_{50}$ value of carbofuran for rat brain AChE.

\begin{tabular}{lcc}
\hline $\begin{array}{l}\text { Carbofuran } \\
(\mu \mathrm{M})\end{array}$ & \% AChE activity remaining & $\begin{array}{c}\text { Activity } \\
(\mu \mathrm{mole} / \mathrm{mL} / \mathrm{min})\end{array}$ \\
\hline 0.00 & 100.00 & 0.1085 \\
0.01 & 45.7841 & 0.04963 \\
0.02 & 40.6919 & 0.04411 \\
0.05 & 37.131 & 0.04025 \\
0.10 & 32.048 & 0.03474 \\
0.20 & 21.3192 & 0.02311 \\
\hline
\end{tabular}

Effect of varying concentrations of carbofuran on the activity of AChE from rat brain was observed by carrying out the enzyme assay employing $100 \mu \mathrm{g}$ protein at $\mathrm{pH} 7.4$ of phosphate buffer as described in Section 2. The enzyme was stored in phosphate buffer $(50 \mathrm{mM}, \mathrm{pH} 7.4)$ containing $0.2 \%$ Triton X100.

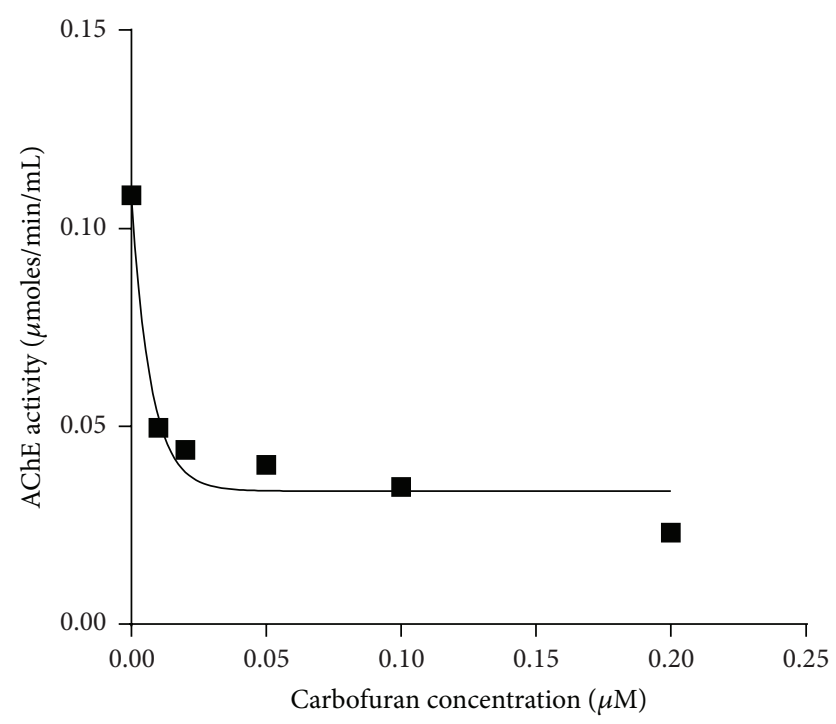

FIgURE 3: Determination of $\mathrm{IC}_{50}$ value of carbofuran for rat brain AChE using the data from Table 5.

in the absence and presence of the pesticide $(2.0 \mathrm{nM})$. The Lineweaver-Burk double reciprocal plot of the data displayed two straight lines parallel to each other intersecting at different points on $Y$ - and $X$-axes, respectively. Using the formula as shown in Section 2.10, $V_{\max }+I\left(V_{\max }\right.$ value in the presence of carbofuran) and $K_{i}$ were calculated, with the values being $0.05 \mu \mathrm{mol} / \mathrm{mL} / \mathrm{min}$ and $5 \mathrm{nM}$, respectively (Figure 4).

\section{Discussion}

The hydrolysis of the neurotransmitter acetylcholine (Ach) to acetic acid and choline by AChE is essential for the transmission of normal nerve impulses at the synapse. The adverse effects of carbofuran in the occupationally exposed people while working in carbofuran infested environments make it imperative to study the impact of carbofuran using the activity of $\mathrm{AChE}$ as a marker. $\mathrm{AChE}$ is known to be

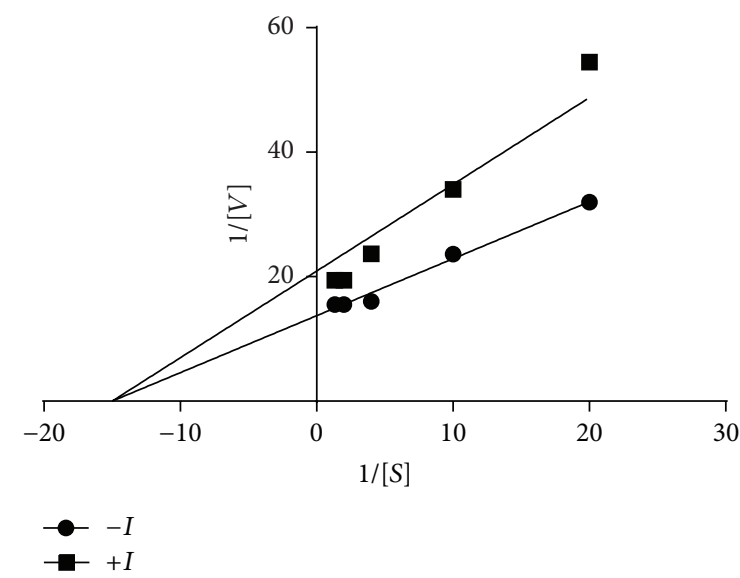

FIGURE 4: Determination of inhibitory action mechanism of carbofuran of AChE. The enzyme $(100 \mu \mathrm{g})$ was assayed at varying concentration ATI at room temperature $\left(26 \pm 2^{\circ} \mathrm{C}\right)$ in the absence (-) and presence ( $\boldsymbol{\square})$ of carbofuran $(2 \mathrm{nM})$ as described in Section 2. The $K_{i}$ and $V_{\max }$ values were calculated using the intersections of the straight line at $Y$ - and at the negative abscissa on $X$-axes, respectively.

responsible for regulating the cholinergic functions and physiological activities of living systems.

The results of the present study indicated that AChE in rat brain was membrane-bound and it could be solubilised by a nonionic detergent, Triton X-100. The extraction and solubilisation of AChE have been made by many workers using various detergents as solubilising agents in both the presence $(0.14 \mathrm{M})$ [23] and the absence of low concentration of $\mathrm{NaCl}$ [24]. It has been reported that mainly the hydrophobic and electrostatic forces are responsible for binding of the AChE with the biological membrane. Possibly, the effect of $\mathrm{NaCl}$ is to weaken the electrostatic interactions with membrane proteins that shields some part of the enzyme from the action of the detergent. Thus, $\mathrm{NaCl}$ facilitates a more effective attack of the detergent on the membrane helping in release of more membrane-bound enzyme in the soluble fraction. There are some reports which suggest that even by this treatment solubilisation of AChE is not completely achieved while using a combination of Triton X100 and $\mathrm{NaCl}$. These findings suggest more tightly bound nature of protein to the membrane. Also, there is a possibility that the enzyme would be shielded by such layers of macromolecules which make actions of Triton X-100 and $\mathrm{NaCl}$ ineffective. Other explanations to the resistance offered by enzyme towards solubilisation could be due to the presence of different molecular forms of enzyme with different modes of membrane anchorage. However, some enzyme activity was observed in the fraction without using Triton X-100 in the extraction medium. This could be because of release of some amount of membrane-bound enzyme due to grinding of the tissues during homogenization process [25]. Recently, acetylcholinesterase has been shown to exist only as membrane-bound form in the human erythrocytes [26]. 
This enzyme was highly stable until 30 days without any significant loss in activity when stored at $-20^{\circ} \mathrm{C}$ carrying out the enzyme assay employing $100 \mu \mathrm{g}$ protein on different days as shown in Table 2. Similar findings have also been reported for the stability of acetylcholinesterase from human erythrocytes [26].

The activity of rat brain AChE showed optimum activity at $\mathrm{pH} 7.4$ and $37^{\circ} \mathrm{C}$. Almost similar results have been presented by Padilla et al. [9]. However, the optimal $\mathrm{pH}$ and temperature requirements vary from one living system to another and also from one organ to another in the same living system. AChE from rat brain possessed MichaelisMenten constant $\left(K_{m}\right)$ value for its substrate (ATI) equal to $0.07 \mathrm{mM}$. Khandkar et al. [27] have reported $K_{m}$ value for human AChE to be $0.98 \mathrm{mM}$, which is very high as compared to that in rat brain as reported in the present study. Roy and Chaudhuri [28] have reported $K_{m}$ value for AChE isolated from different parts of the rat brain; the values were 2.63, 4.54 , and $5.0 \mathrm{mM}$ for AChE of cerebrum, hypothalamus, and cerebellum, respectively. The present study has included the $K_{m}$ value $(70 \mu \mathrm{M})$ for the total $\mathrm{AChE}$ isolated from all parts of the rat brain. However, the $K_{m}$ values reported by Roy and Chaudhuri [28] are about 37-70-fold higher; the reasons for that are not clear. In another study, Jadhav et al. [29] have shown $K_{m}$ value for AChE from rat brain to be $59 \mu \mathrm{M}$, which is quite close to that obtained in the present study.

The $\mathrm{IC}_{50}$ value of carbofuran for AChE from the rat brain was found to be $6.0 \mathrm{nM}$. Smulders et al. [30] have reported $\mathrm{IC}_{50}$ values for rat brain $\mathrm{AChE}$ using different pesticides of organocarbamate group. The values recorded indicated that the potency order of these carbamates to inhibit rat brain acetylcholinesterase is bendiocarb > propoxur, aldicarb $>$ carbaryl 》S-ethyl N,N-dipropylthiocarbamate (EPTC), fenoxycarb with $\mathrm{IC}_{50}$ values ranging from $1 \mathrm{M}$ for bendiocarb to $17 \mathrm{M}$ for carbaryl, and $\gg 1 \mathrm{mM}$ for EPTC and fenoxycarb. The $\mathrm{IC}_{50}$ value of carbofuran for AChE isolated from erythrocytes of rat was $33 \mathrm{nM}$ [30]. $\mathrm{IC}_{50}$ values for different carbamates vary depending on their molecular size. The variations in the $\mathrm{IC}_{50}$ value from 33 to $307 \mu \mathrm{M}$ for different carbamate inhibitors could be partly due to different tissues and experimental conditions employed such as temperature, $\mathrm{pH}$, and incubation time [31]. Analysis of agricultural products in India showed contamination with pesticide residues. Data for pesticide residues from selected fields are being generated by various agricultural universities and Indian Council of Agricultural Research Institutions in the country (ICARs). The percent presence of pesticide residues observed in the samples was found to be 60.6 for carbofuran. For carbofuran the pesticide residues was detected, reported to be in the range of 50-1200 ng/lit. The pesticide residues have also been reported to be present in nonagricultural products for public consumption like meat, fish, and milk.

In the present investigation, carbofuran displayed inhibition of rat brain $\mathrm{AChE}$ in noncompetitive manner with $K_{i}$ value being $5 \mathrm{nM}$, thereby reducing the $V_{\max }$ value with an unchanged substrate affinity to the enzyme, that is, $K_{m}$ value. Since $V_{\max }$ changes and $K_{m}$ remains constant, the ratio of $K_{m} / V_{\max }$ gives rise to straight lines corresponding to the uninhibited and inhibited reactions in Lineweaver-Burk double reciprocal plot. This kind of inhibition of rat brain AChE suggested that carbofuran was binding somewhere on the surface of the enzyme protein and thereby influencing the catalytic pocket in a way to reduce the velocity of reaction without influencing the affinity. The action of carbofuran in the biological systems is mediated through binding with the hydroxyl group of serine residue located at the enzyme's active site. The noncompetitive inhibition by carbofuran suggests that it has other interaction sites different from the catalytic sites in the enzyme. It could be further ascertained by performing detailed investigation using suitable bioinformatics tools. However, the presence and role of serine residue in the active site pocket responsible for the enzyme catalysis could be ascertained by the site directed mutagenesis.

\section{Conclusion}

Rat brain AChE was found to be membrane-bound which could be solubilised by using Triton X-100, a nonionic detergent. The significant inhibition of AChE activity in rat brain by carbofuran indicates that the compound even at very low concentration $\left(K_{i} 5 \mathrm{nM}\right)$ is extremely neurotoxic to the mammals. Interestingly, carbofuran was able to significantly reduce $\mathrm{AChE}$ activity with respect to increasing incubation time for enzyme-inhibitor complex. Similar to the results from other studies, this investigation also suggests that rat brain AChE contains at least one serine residue at the catalytic pocket which is carbamylated by carbofuran causing inhibition of the enzyme in a noncompetitive manner. This event results in reduction of the maximum velocity of reaction $\left(V_{\max }\right)$ but there is any impact of affinity of enzyme to the substrate. The results of this study clearly indicated that AChE from rat brain might serve as a biomarker of carbofuran induced toxicity in those occupants staying in pesticide infested environment.

\section{Competing Interests}

The authors declare that they do not have any competing interests.

\section{Acknowledgments}

Vivek Kumar Gupta is grateful to the University Grant Commission, New Delhi, for providing research scholarship for this work at the Department of Biochemistry, University of Allahabad, India. Nikhat Jamal Siddiqi gratefully thanks the Research Center, Female Center for Scientific and Medical Colleges, King Saud University, Riyadh, for the support.

\section{References}

[1] R. C. Gupta, "Carbofuran toxicity," Journal of Toxicology and Environmental Health, vol. 43, no. 4, pp. 383-418, 1994.

[2] J. Rendón-Von Osten, A. M. V. M. Soares, and L. Guilhermino, "Black-bellied whistling duck (Dendrocygna autumnalis) brain cholinesterase characterization and diagnosis of anticholinesterase pesticide exposure in wild populations from 
Mexico," Environmental Toxicology and Chemistry, vol. 24, no. 2, pp. 313-317, 2005.

[3] R. M. Whyatt, D. B. Barr, D. E. Camann et al., "Contemporaryuse pesticide in personal air samples during pregnancy and blood samples at delivery among urban minority mothers and newborns," Environmental Health Perspectives, vol. 111, no. 5, pp. 749-756, 2003.

[4] M. Kaur and R. Sandhir, "Comparative effects of acute and chronic carbofuran exposure on oxidative stress and drugmetabolizing enzymes in liver," Drug and Chemical Toxicology, vol. 29, no. 4, pp. 415-421, 2006.

[5] D. K. Rai, P. K. Rai, S. I. Rizvi, G. Watal, and B. Sharma, "Carbofuran-induced toxicity in rats: protective role of vitamin C," Experimental and Toxicologic Pathology, vol. 61, no. 6, pp. 531-535, 2009.

[6] D. K. Rai, R. K. Sharma, P. K. Rai, G. Watal, and B. Sharma, "Role of aqueous extract of Cynodon dactylon in prevention of carbofuran-induced oxidative stress and acetylcholinesterase inhibition in rat brain," Cellular and Molecular Biology, vol. 57, no. 1, pp. 135-142, 2011.

[7] A. Agrawal and B. Sharma, "Pesticides induced oxidative stress in mammalian systems: a review," International Journal of Biological and Medical Research, vol. 1, no. 3, pp. 90-104, 2010.

[8] D. Milatovic, R. C. Gupta, and M. Aschner, "Anticholinesterase toxicity and oxidative stress," TheScientificWorldJournal, vol. 6, pp. 295-310, 2006.

[9] S. Padilla, R. S. Marshall, D. L. Hunter, and A. Lowit, "Time course of cholinesterase inhibition in adult rats treated acutely with carbaryl, carbofuran, formetanate, methomyl, methiocarb, oxamyl or propoxur," Toxicology and Applied Pharmacology, vol. 219, no. 2-3, pp. 202-209, 2007.

[10] D. K. Rai and B. Sharma, "Carbofuran-induced oxidative stress in mammalian brain," Molecular Biotechnology, vol. 37, no. 1, pp. 66-71, 2007.

[11] B. Kaur, A. Khera, and R. Sandhir, "Attenuation of cellular antioxidant defense mechanisms in kidney of rats intoxicated with carbofuran," Journal of Biochemical and Molecular Toxicology, vol. 26, no. 10, pp. 393-398, 2012.

[12] R. K. Sharma and B. Sharma, "In-vitro carbofuran induced genotoxicity in human lymphocytes and its mitigation by vitamins C and E," Disease Markers, vol. 32, no. 3, pp. 153-163, 2012.

[13] M. G. Lionetto, R. Caricato, A. Calisi, M. E. Giordano, and T. Schettino, "Acetylcholinesterase as a biomarker in environmental and occupational medicine: new insights and future perspectives," BioMed Research International, vol. 2013, Article ID 321213, 8 pages, 2013.

[14] A. G. E. Pearse, "Histochemistry: theoretical and applied," in Histochemistry, vol. 2, chapter 17, pp. 761-807, ChurchillLivingstone, London, UK, 3rd edition, 1972.

[15] H. H. Dale, "The action of certain esters of cholme and then relation to muscarme," Journal of Pharmacology and Experimental Therapeutics, vol. 6, pp. 147-190, 1914.

[16] A. Silver, The Biology of Cholinesterases, North Holland, Amsterdam, Netherlands, 1974.

[17] T. L. Rosenberry, "Acetylcholmesterase," Advances in Enzymology, vol. 43, pp. 103-218, 1975.

[18] A. J. Trevor, M. A. Gordon, K. K. Parker, and S.-L. Chan, "Acetylcholinesterases," Life Sciences, vol. 23, no. 12, pp. 12091220, 1978.
[19] J. Massoulié and S. Bon, “The molecular forms of cholinesterase and acetylcholinesterase in vertebrates," Annual Review of Neuroscience, vol. 5, pp. 57-106, 1982.

[20] S. Brimijoin, "Molecular forms of acetylcholinesterase in brain, nerve and muscle: nature, localization and dynamics," Progress in Neurobiology, vol. 21, no. 4, pp. 291-322, 1983.

[21] O. H. Lowry, N. J. Rosebrough, A. L. Farr, and R. J. Randall, "Protein measurement with the Folin phenol reagent," The Journal of Biological Chemistry, vol. 193, no. 1, pp. 265-275, 1951.

[22] G. L. Ellman, "Tissue sulfhydryl groups," Archives of Biochemistry and Biophysics, vol. 82, no. 1, pp. 70-77, 1959.

[23] G. Civenni, S. T. Test, U. Brodbeck, and P. Butikofer, "In vitro incorporation of GPI anchored proteins and their fate in the membrane," Blood, vol. 91, pp. 1784-1792, 1998.

[24] B. Sharma, "Some properties of partially purified acetylcholinesterase from the adult female filarial parasite, Setaria cervi," Helminthologia, vol. 33, no. 1, pp. 13-20, 1996.

[25] J. Massoulié, L. I. Pezzementi, S. Bon, E. Krejci, and F.-M. Vallette, "Molecular and cellular biology of cholinesterases," Progress in Neurobiology, vol. 41, no. 1, pp. 31-91, 1993.

[26] V. K. Gupta, R. Pal, N. J. Siddiqi, and B. Sharma, "Acetylcholinesterase from human erythrocytes as a surrogate biomarker of lead induced neurotoxicity," Enzyme Research, vol. 2015, Article ID 370705, 7 pages, 2015.

[27] M. A. Khandkar, E. Mukherjee, D. V. Parmar, and S. S. Katyare, "Alloxan-diabetes alters kinetic properties of the membranebound form, but not of the soluble form, of acetylcholinesterase in rat brain," Biochemical Journal, vol. 307, no. 3, pp. 647-649, 1995.

[28] R. Roy and A. N. Chaudhuri, "Differential acetylcholinesterase activity in rat cerebrum, cerebellum and hypothalamus," Indian Journal of Experimental Biology, vol. 44, no. 5, pp. 381-386, 2006.

[29] K. B. Jadhav, S. Shivaya, H. Prasad et al., "Comparative responses of acetylcholinesterase (AChE) of rat brain and model invertebrate Caenorhabditis elegans in vitro," Applied Biological Research, vol. 16, no. 2, pp. 169-175, 2014.

[30] C. J. Smulders, T. J. Bueters, R. G. Van Kleef, and H. P. Vijverberg, "Selective effects of carbamate pesticides on rat neuronal nicotinic acetylcholine receptors and rat brain acetylcholinesterase," Toxicology and Applied Pharmacology, vol. 193, no. 2, pp. 139-146, 2003.

[31] D. K. Rai and B. Sharma, "On the neurotoxicity of carbofuran in mammalian system," in Proceedings of the 4th International Academic Conference on Environmental and Occupational Medicine, pp. 71-79, Shanghai, China, October 2006. 

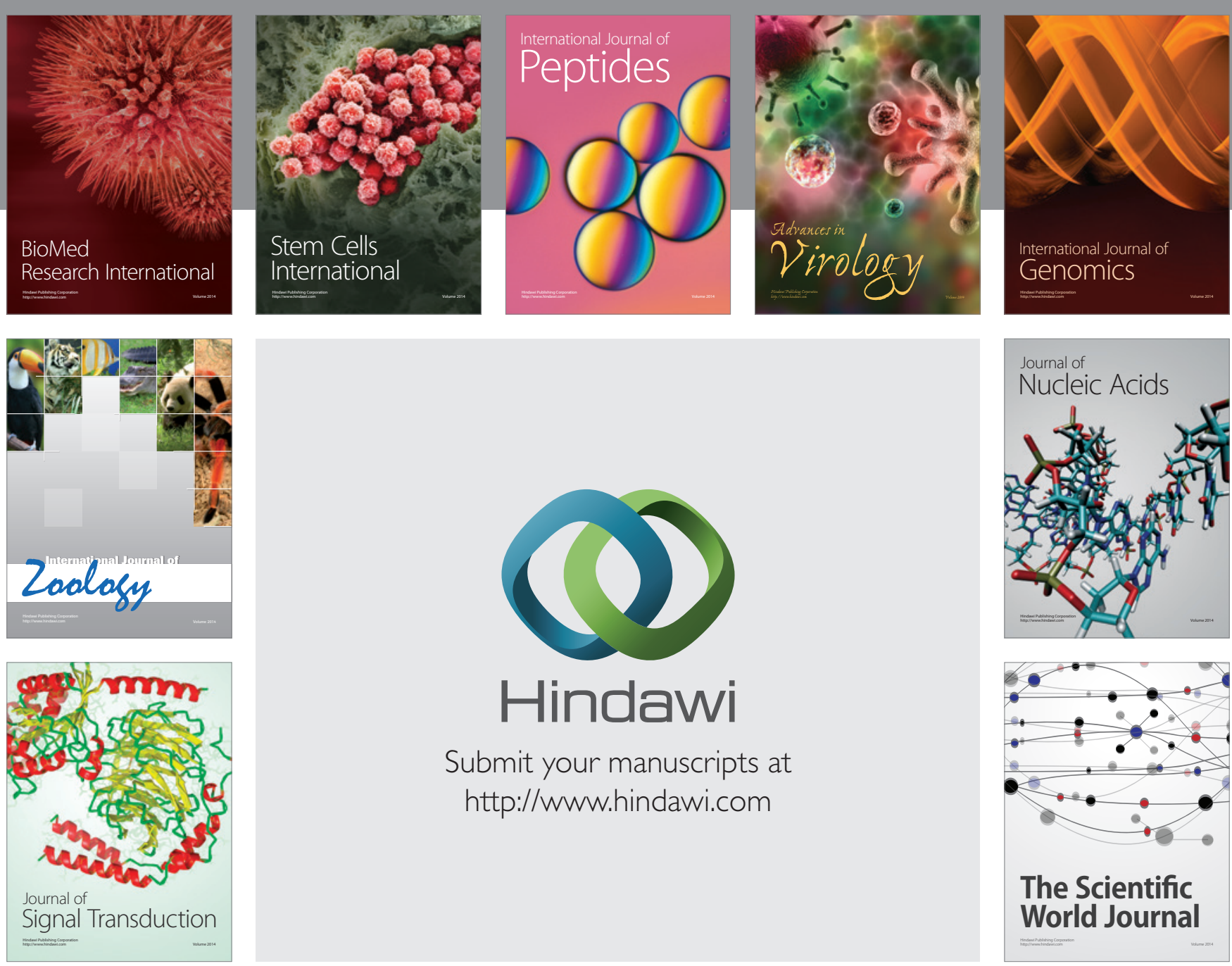

Submit your manuscripts at

http://www.hindawi.com
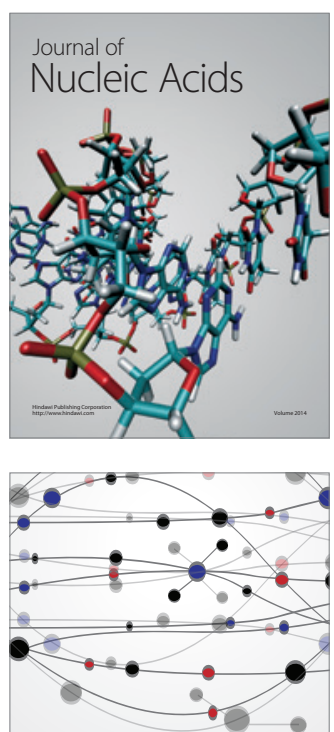

The Scientific World Journal
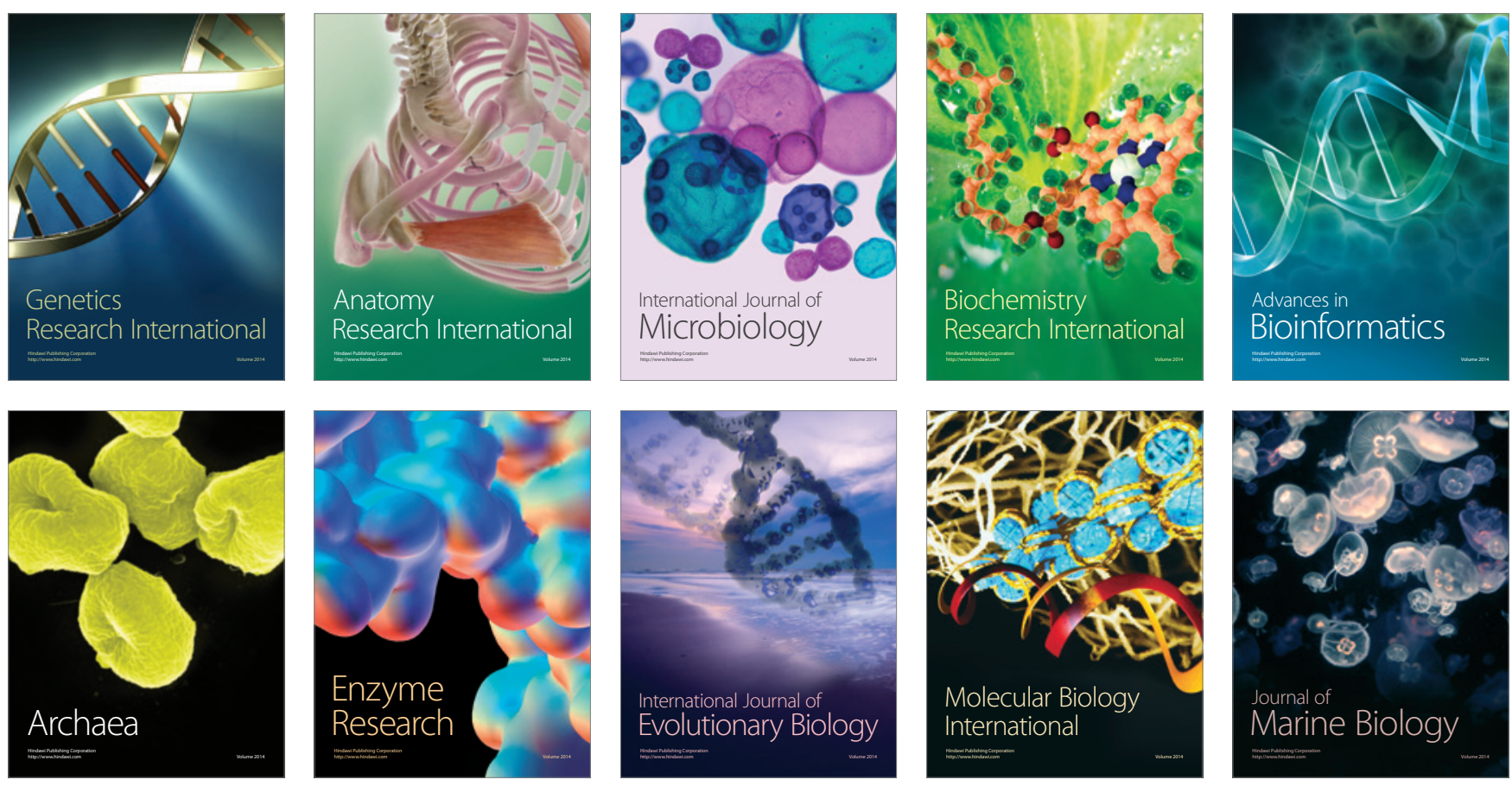